\title{
The Effect of Health and Religious Beliefs on Consumer Consciousness of Using Halal Cosmetics
}

\author{
Sri Wahyuni Hasibuan ${ }^{1}$, Yasir Nasution ${ }^{2}$, Safaruddin Siregar ${ }^{2}$ \\ ${ }^{1}$ Ph.D Student in State Islamic University of North Sumatera (UINSU), Medan, Indonesia \\ ${ }^{2}$ Lectures in State Islamic University of North Sumatera (UINSU), Medan, Indonesia \\ yuni.hsb@gmail.com
}

\begin{abstract}
The purpose of this study is to analyze in depth the effect of health and religious beliefs on consumer consciousness of using halal cosmetics. The subjects of this study are adult women who use cosmetics labeled halal and domiciled in Medan city. The number of samples is 100 people based on convenience sampling. Questionnaire is a data collection tool used in this study while the type is quantitative research. The analysis technique uses a variance-based SEM (PLS) approach with the Smart PLS 3 program. The findings of this study are that health and religious beliefs have a significant and positive effect on consumer consciousness of using halal cosmetics. The government, producers and cosmetics users must know that the concept of halal in cosmetics can be used as a global symbol to ensure the quality of the lifestyle of cosmetic consumers in the world. Because halal has positive scores for all lines of society. As healthy, clean, and protected from harmful ingredients. So this study recommends the need for the government which has the authority to consider halal cosmetic concepts to make regulations in producing cosmetics. Whereas for producers is a business opportunity or strategy to get more income. Because someone will be more aware of a positive after experiencing the effects of consuming something that can endanger her life.
\end{abstract}

Keywords : Consciousness; health; religious beliefs; halal cosmetics.

\section{Introduction}

The market potential of the world's halal products is expected to develop rapidly along with the soaring world Muslim community. This development can also be caused by consumer consciousness of halal products. Realizing that halal scores are actually more than religious matters but have good scores for all the ummah. According to Thompson's report, halal cosmetics is one of the halal products in Indonesia which ranks $8^{\text {th }}$ as a player, so that it has the potential to export halal cosmetic products to the international market. According to a report from the Indonesian trade ministry, PT Paragon Technology and Innovation (PTI) has met the challenge in including halal labels in its cosmetic products, namely Wardah. Consumers are aware of halal products can be caused by various factors. Halal label is one of the things that can attract buyers. Schiffman \& Kanuk argues that members of various purchasing decisions of religious groups are effectd by their religious beliefs. In addition, the high level of knowledge and understanding of religious beliefscan affect consciousness of halal cosmetics. But there is also someone who is unconscious because of the lack of knowledge of religious beliefs. Although Indonesia has a halal cosmetics market potential, but consciousness of halal cosmetics is still low or not comparable with the potential that exists with consumer supply that is ranked $4^{\text {th }}$ (Thompson Reuters Report, 2014 s / d2017).

Consumers' consciousness of using halal cosmetics can also be caused by health factors. Now with the many illegal and dangerous cosmetics circulating, consumers are increasingly careful in choosing cosmetics to buy, because they are afraid to damage their skin. As in the findings of Ambalia and Bakara, health factors are the variables that most effect the level of halal consciousness. But despite the fact that there are also those who do not care about ingredients made for cosmetics. 
Medan City is a multi-ethnic city, Medan is also known as a city with a variety of religious beliefss which means it should sell and buy products that have halal labels. Islam is one of the religious beliefss adopted by the people in the city of Medan. Islam teaches that as a Muslim it is an obligation to use halal cosmetics even though they are not praying. Many cosmetic brands in the market can confuse consumers to choose the cosmetics they will use. Therefore it is very important to know the level of consciousness of consumers using halal cosmetics. It is also the purpose of this research which is to know (a) the effect of health on consciousness, (b) the effect of religious beliefson consciousness.

\section{Review of Literatures}

\subsection{Halal Cosmetics}

Wilson and Liu argue that halal is a central concept for sharia and Muslim beliefs, which includes a broader philosophy than just a product brand or marketing; it is ethos and moral code of ethics with a strong ethical attitude. While Toyyiban is another central concept of Sharia, with broader meanings related to virtue, linking goodness, cleanliness, health, and security (Noordin et al, 2009). These two central concepts suggest a more balanced, sustainable, and humane approach to systems and practices. These concepts broadly effect consumer consciousness of halal cosmetics which are the conceptual basis of a holistic brand lies in the spiritual ethos and has an impact on the imaging of a brand and reflects a particular worldperspective, rooted in a belief system.

Cosmetics are a product that is used in the human body to beautify, cleanse, promote attraction, or change appearance without affecting body functions (Cosmetics and Your Health, 2018). Whereas etymologically halalan is anything that is permissible and can be done on the grounds that it is free from the conditions that prohibit it. Simply interpreted things that are free from the dangers of the world and the hereafter. Thayyib means delicious, healthy, good, reassuring, most important (Abdul Aziz, 2003).

According to the Islamic perspective, objects that can be consumed are just something that shows the scores of chastity, kindness, beauty, and raises benefits for the ummah both spiritually and materially. On the contrary, everything that is bad, impure, worthless, cannot be used and also cannot be considered as consumer goods in Islam and can cause harm if consumed will be prohibited (Al Arief and Amalia, 2014).

Based on the above foundation, what is meant by halal cosmetics is a cosmetic that is not made from unclean substances, dangerous substances, and clean from dirt, giving scores of purity, kindness, health, safety, beauty, and creating benefits for the ummah both spiritually and material.

\subsection{Consciousness}

According to Chartrand consciousness is an element that appears in human automatic processes. Automaticity can involve consciousness or unconscious actions. The process consists of environmental features, automatic processes and results (see Figure 1) 


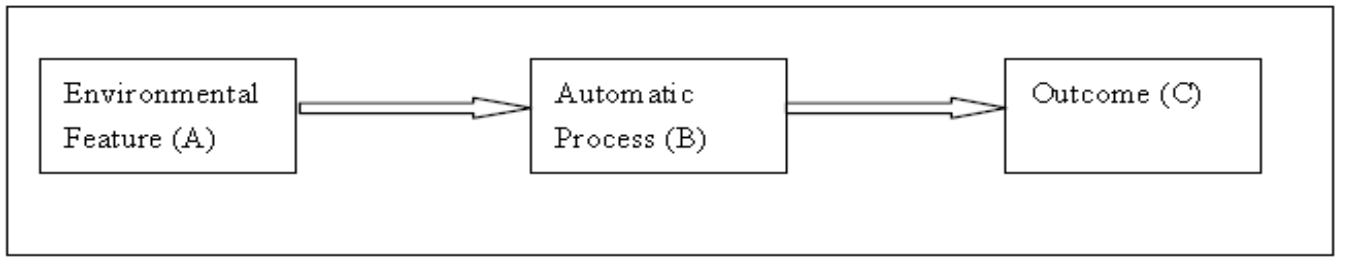

Figure 1. Automatic process model

As shown in the figure above, environmental features (labeled as A) can include situations, the presence of other people, events and others that can trigger automatic processes. Automatic processes (labeled as B) include processes such as attitude activation, automatic evaluation, unconsciousness and activation of stereotypes. Meanwhile, outcomes (labeled as C) can include items such as behavior, motivation, judgment, decisions and emotions. "Consciousness" can be positioned in all three automatic processes (A, B and C). For example, the idea proposed by a chemical waste disposal plant in a nearby area has functioned as an environmental feature that automatically triggered the process of rejecting the idea. Individual rejection can be driven consciously or unconsciously. People can act consciously because they are experts in the effects of radiation; instead, he may act unconsciously over environmental features when he only follows the actions of the majority of certain groups.

According to Chartrand, consumer consciousness (whether consciously or unconsciously) precedes control, modification, elimination and changes in human behavior and decisions. So, consumers who behave effectively can only be realized through consciousness. In Alqu'ran there is a tendency for humans to lose consciousness in assessing something good and positive (Q.S Al-baqarah: 2/9). So humans have a tendency to do something that has a negative effect in an unconscious state. They choose cosmetics from unsanitary elements because they are unconscious and have low knowledge. Conversely for people who choose to use cosmetics that are not harmful to health are people who already understand or have a strong motivation for cosmetics.

\subsection{Health}

Health problems are related to religious beliefs, Islam prohibits cosmetics that harm the body, this concept is in line with the general perspective that health is very important. This perspective was justified by Louren and Tournis in their research that Dr. Mah Hussain Gambles noted: The cosmetics industry benefited from increasing concerns about the use of hazardous ingredients in cosmetics and $75 \%$ of its customers were non-Muslims. The high concern about using dangerous cosmetics and health reasons is one that gives consumers consciousness to use cosmetics.

\subsection{Religious Beliefs}

In addition to health factors, religious beliefs are the main factor that encourages consumers to consume cosmetics. Knowledge of religious beliefs or belief is the best guide for knowing which cosmetics can be used. According to Said (1997) Islam is a system of beliefs and comprehensive actions that govern faith, individuals, and society and transcend the material world. The main basis of Islamic rule is Shari'ah. Shari'ah Islam regulates all aspects of life including consumption behavior. Including regulating cosmetics that may be used by Muslims, namely halal cosmetics. Some consumption restrictions are the prohibition of pork, 
dogs and non-meat from the slaughter for Islam, beef in Hinduism and Buddhism, peace of mind for the Vegetarian community, except Christianity which does not have taboo in consuming.

\section{Research Methods}

\subsection{Data collection}

The research population is adult women who are Muslim. The number of samples is 100 people with qualifications aged 20-44 years and using cosmetics that have a halal label. The collection of samples according to certain qualifications is done by convenience sampling (Kuncoro, 2003). The data in this study were taken from respondents through a list of questions adopted from previous research. Data retrieval is carried out by asking informants to fill in the questionnaire provided themselves. Furthermore, the data obtained from the results of the questionnaire was entered into excel, then analyzed by PLS SEM and using a Smart PLS 3.0 tool.

\subsection{Goodness of Measures for Instrumentation}

The instrument in this study was made in the form of a Likert scale questionnaire that was adopted and modified so that it could form a research model. Statements or questions are obtained from in-depth studies of previous research, that is consumer consciousness of halal cosmetics, health and religious beliefs (Isabelle \& Laurent, 2015, Ambalia \& Bakara, 2014, Azmawani et al., 2013, Syazwan, 2016, Jihan et al, 2013, and Talisa, 2017). The researchers divided the Likert scale into 5 (five) continuum and each was given a score. The statement / question uses the option strongly agree, agree, disagree, less agree, and strongly disagree. The statement answered by the respondent is in the form of a positive score of 5,4,3,2,1. After the data is obtained, the next step is to analyze the structural model, analyze the measurement model and test the hypothesis.

\subsubsection{Structural Model Analysis}

\section{a. Cross Loading}

Cross Loading is a construct relationship with measurement items greater than the size of other constructs, so it shows that latent constructs predict the size of their blocks better than other block sizes (Fornell and Lasrcker, 1981). The score expected in this study is 0.70 . For more details, can be seen in the table below:

Table 1. Cross Loading

\begin{tabular}{|l|l|l|l|}
\hline Variable & Consciousness & Health & $\begin{array}{l}\text { Religious } \\
\text { beliefs }\end{array}$ \\
\hline AGM_2 & 0.385 & 0.295 & $\mathbf{0 . 7 1 6}$ \\
\hline AGM_3 & 0.478 & 0.223 & $\mathbf{0 . 8 7 9}$ \\
\hline AGM_4 & 0.502 & 0.359 & $\mathbf{0 . 8 1 9}$ \\
\hline SDR_1 & $\mathbf{0 . 8 5 0}$ & 0.548 & 0.556 \\
\hline SDR_2 & $\mathbf{0 . 7 7 7}$ & 0.426 & 0.511 \\
\hline SDR_3 & $\mathbf{0 . 8 7 1}$ & 0.530 & 0.501 \\
\hline SDR_4 & $\mathbf{0 . 7 7 6}$ & 0.522 & 0.253 \\
\hline SHT_2 & 0.402 & $\mathbf{0 . 7 3 0}$ & 0.264 \\
\hline SHT_3 & 0.567 & $\mathbf{0 . 8 7 4}$ & 0.334 \\
\hline SHT_4 & 0.520 & $\mathbf{0 . 8 2 6}$ & 0.281 \\
\hline
\end{tabular}


It can be concluded that the correlation of the score of each construct is higher than the other dimensions. This indicates that each latent construct is better than the other block sizes.

\section{b. Convergent Validity}

Convergent validity can be seen from the extracted average variance score (Average Variance Extracted). The threshold score is 0.5. In this study the AVE scores of each construct are at 0.651 to 0.672 . Therefore there are no problems with convergent validity on the model being tested. For details, can be seen in the following table:

Table 2. Average Variance Extracted (AVE)

\begin{tabular}{|l|l|}
\hline \multicolumn{1}{|c|}{ Construct } & AVE \\
\hline Consciousness & 0,672 \\
\hline Health & 0,660 \\
\hline Religious beliefs & 0,651 \\
\hline
\end{tabular}

Source: 2018 primary data processed

c. Discriminant Validity

Discriminant validity can be seen by comparing the score of the square root Average Variance Extracted with the score of the correlation between constants.

Table 3. Score of Square Root AVE

\begin{tabular}{|l|l|l|l|l|}
\hline & Consciousness & Health & $\begin{array}{l}\text { Religious } \\
\text { beliefs }\end{array}$ & $\begin{array}{l}\text { Merek } \\
\text { Holistic }\end{array}$ \\
\hline Consciousness & $\mathbf{0 , 8 2 0}$ & & & \\
\hline Health & 0,618 & $\mathbf{0 , 8 1 2}$ & & \\
\hline Religious beliefs & 0,568 & 0,362 & $\mathbf{0 , 8 0 7}$ & \\
\hline
\end{tabular}

The table above shows that the AVE square root score $(0.820,0.812,0.807)$ is greater than the correlation of each construct. As for other ways that can be used to test discriminant validity by looking at the cross loading table. From the results of the table above it appears that there are no discriminant validity problems.

d. Reliability

To confirm that there are no problems related to measurement, the final step in the measurenment model evaluation is to test the unidimensionality of the model. This test is carried out using the reliability composite indicator and Cronbach alpha. For these two indicators the cut-off point is 0.7 .

Table 4. Cronbach's Alpha and Composite Reliability

\begin{tabular}{|l|c|c|}
\hline \multicolumn{1}{|c|}{ Variable } & Cronbach's Alpha & Composite Reliability \\
\hline Consciousness & 0,837 & 0,891 \\
\hline Health & 0,742 & 0,853 \\
\hline Religious beliefs & 0,730 & 0,847 \\
\hline
\end{tabular}

Source: 2018 primary data processed 
Table 4 above shows that all constants have composite reliability scores ranging from 0.891 to 0.847 . It can be concluded that the data collected has been considered reliable and trustworthy, because it produces a composite composite $>0.7$. This reliability test is also strengthened with Cronbach Alpha. The alpha cronbach scores of all constructs ranged from 0.730 to 0.837 . Cronbach alpha score is set $>0.6$ for all constructs.

\subsubsection{Structural Model Analysis}

Evaluation of this structural model can be done in three ways. All three are seen from the score of R Square, Q2, and GoF.

Table 5. R Square

\begin{tabular}{|l|l|}
\hline Construct & Score R Square \\
\hline Consciousness & 0,519 \\
\hline
\end{tabular}

Source: 2018 primary data processed

Based on the table above the score of $\mathrm{R}$ Square is 0.519 . This shows that the magnitude of the diversity of models in this study was $51.9 \%$. While $41.9 \%$ is explained by other factors. The last is to find the score of Goodness of Fit (GoF). According to Tenenhaus (2005), the score of GoF is small $=0.1$, medium $\mathrm{GoF}=0.25$ and large $\mathrm{GoF}=0.38$. Unlike CB-SEM, GoF scores on PLS-SEM must be searched manually.

$$
\begin{aligned}
& \text { Gof }=\sqrt{\overline{A V E \times \overline{R^{2}}}} \ldots \ldots \ldots \ldots . . . \text { Tenennhauses }(2005) \\
& \text { Gof }=0,781 \times 0,720 \\
& \text { Gof }=0,562
\end{aligned}
$$

Based on the calculation results above the score of Goodness of Fit (GoF) is 0.562. This shows that the GoF index score is included in the big category and the model that has been formed in this study is good.

\section{Discussion}

\subsection{Characteristics of Respondents}

Distribution of respondents' characteristics is the number of respondents based on their categorization, which can be seen in the table below:

Table 6. Summary of Characteristics of Respondents

\begin{tabular}{|l|l|c|c|}
\hline \multicolumn{1}{|c|}{ Characteristics } & \multicolumn{1}{|c|}{ Category } & Frequency & Percentage \\
\hline Ages & 20-24 Years & 35 & $35 \%$ \\
& 25-29 Years & 20 & $20 \%$ \\
& 30-34 Years & 24 & $24 \%$ \\
& 35-39 Years & 11 & $11 \%$ \\
& 40-44 Years & 10 & $10 \%$ \\
\hline Education & Diploma & 7 & $7 \%$ \\
& Bachelor & 75 & $75 \%$ \\
& Senior High School & 17 & $17 \%$ \\
& Junior High School & 1 & $1 \%$ \\
\hline Jobs & Doctor & 4 & $1 \%$ \\
& Lecturer & & $4 \%$ \\
\hline
\end{tabular}




\begin{tabular}{|l|l|c|c|}
\hline & IRT & 7 & $7 \%$ \\
& College student & 32 & $32 \%$ \\
& Government employees & 20 & $20 \%$ \\
& Private employees & 26 & $26 \%$ \\
& Unemployment & 1 & $1 \%$ \\
& entrepreneur & 9 & $9 \%$ \\
\hline Halal Labeled Cosmetic & Mazaya & 4 & $4 \%$ \\
Brand That Has Been Used & SAFI & 1 & $1 \%$ \\
& Wardah & 86 & $86 \%$ \\
& Zoya & 4 & $4 \%$ \\
& Lainnya & 5 & $5 \%$ \\
\hline
\end{tabular}

The table above shows that the majority of respondents were at the age of 20-24 years, namely as many as 35\%, followed by respondents aged 30-34 years, as many as $24 \%$. Furthermore, the educational qualifications of most of the respondents were undergraduate as many as 75 respondents, followed by senior high school graduates as much as $17 \%$. Whereas in job qualifications most of the respondents were students as much as $32 \%$, followed by the employment status of private employees as much as $26 \%$. Finally, based on the qualification of the halal labeled cosmetic brand that was used, most respondents used the wardah brand, which was $86 \%$ of respondents.

\subsection{Description of Research Data}

\subsubsection{Consciousness}

The results of the distribution of data with an average score of health variable instruments are $89.65 \%$, where the highest score of $92 \%$ is found in the indicator "using halal and good cosmetics", $90 \%$ is in the indicator "seeking information about halal cosmetic clarity", $89.8 \%$ found in the indicator "knowing halal cosmetics are beauty products that are in accordance with Islamic religious beliefs", and the lowest score was $86.8 \%$ in the indicator "avoiding cosmetic products that are not clearly halal (subhat)".

\subsubsection{Health}

The results of the distribution of data with a score of the average score of health variable instruments were $86.95 \%$, where the highest score of $89.6 \%$ was found in the indicator "halal cosmetics are healthy cosmetics and healthy cosmetics are a symbol of cleanliness, safety and high quality", $86.8 \%$ is found in the indicator "halal cosmetics are beauty products free of hazardous chemicals", $86.2 \%$ are in the indicator "I have to use halal cosmetics to have healthier and hygienic skin", and the lowest score is obtained. $85.4 \%$ is in the indicator "I can prevent skin diseases by using halal cosmetics".

\subsubsection{Religious Beliefs}

The distribution of data with an average score of $88.53 \%$ of religious belief variable instruments, where the highest score of $90.2 \%$ is found in the indicator "believe that you must strictly prohibit yourself from using non-halal cosmetics as ordained by religious teachings Islam", 88\% is in the indicator "believe that using halal cosmetics is obedient to Islamic orders", and the lowest score is $87.4 \%$ in the indicator" Believing that using non-halal cosmetics is a sin for the Muslims ". 


\subsection{Test the Research Hypothesis}

Tests were conducted to analyze the proposed hypothesis, namely the effect of exogenous latent variables with endogenous variables. Based on the analysis of effect analysis using Smart PLS Version 3 for each variable, namely religious beliefs, health, and consciousness are as shown in the following figure and table:

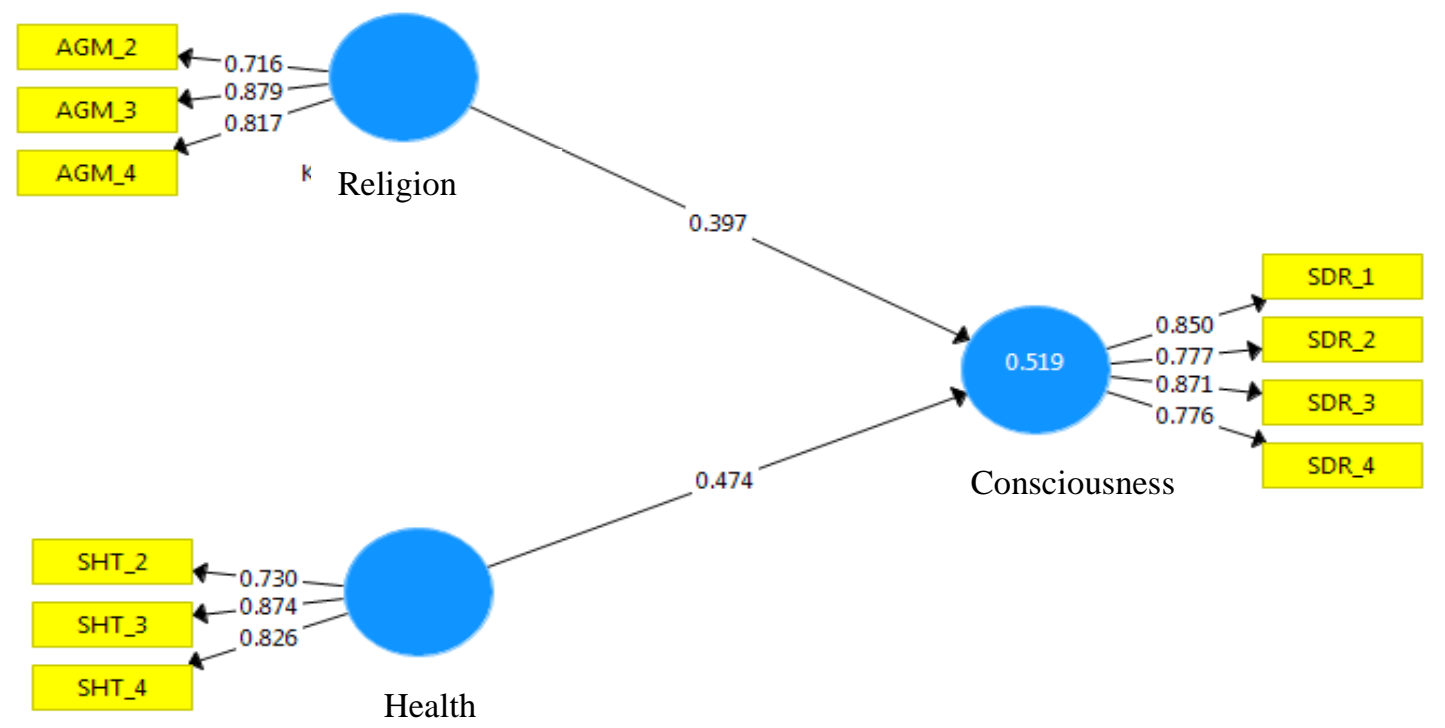

The score of $\mathrm{R}$ Square is the coefficient of determination in endogenous constructs. According to Chin (1998), the score of $\mathrm{R}$ square is 0.67 (strong), 0.33 (moderate) and 0.19 (weak). The picture above shows the score of endogenous variables of consciousness above 0.33 , namely moderate. Based on these results it can be concluded that the score of R2 0.519 indicates that the $51.9 \%$ level of consciousness of using halal cosmetics can be explained by religious and health beliefs.

Table 7. Path Coefficient

\begin{tabular}{|l|l|l|l|l|l|l|}
\hline Hypothesis & Effect & $\begin{array}{l}\text { Original } \\
\text { Sample } \\
(0)\end{array}$ & $\begin{array}{l}\text { Mean } \\
(\mathrm{M})\end{array}$ & $\begin{array}{l}\text { Standard } \\
\text { Deviation } \\
(\text { STDEV) }\end{array}$ & $\begin{array}{c}\text { T } \\
\text { Statistic }\end{array}$ & $\begin{array}{c}\text { P } \\
\text { Scores }\end{array}$ \\
\hline H1 & Health $\rightarrow$ Consciousness & 0,474 & 0,475 & 0,089 & 5,328 & 0,000 \\
\hline H2 & Religious beliefs $\rightarrow$ Consciousness & 0,397 & 0,405 & 0,075 & 5,273 & 0,000 \\
\hline
\end{tabular}

$* * \mathrm{p}<0.05$

$* * \mathrm{t}-$ statistic $>1.96$

Based on the table above, it can be interpreted that the original health sample score of consciousness produces a score of $0.474>0.05$ and produces a score of $t$ statistic $5.328>\mathrm{t}$ table 1.96, which shows a positive and significant effect. While the original sample score of 
religious beliefs on consciousness produces a score of $0.397>0.05$ and produces a score of $t$ statistic $5.273>$ t table 1.96, which shows a positive and significant effect.

The findings show that Muslim adult women in Medan city are very aware of using halal cosmetics with an average score of $89.65 \%$. The indicators that show consciousness are (1) they know halal cosmetics are beauty products that are in accordance with Islamic religious beliefs; (2) they avoid cosmetic products that are not clearly halal (subhat); (3) they use halal and good cosmetics and (4) they seek information about the clarity of halal cosmetics. Indirectly the indicator supports the opinion of Chartrand (2005) that consumer consciousness (whether consciously or unconsciously) precedes control, modification, elimination and changes in human behavior and decisions.

In addition, adult women who are Muslim and domiciled in Medan City strongly believe in halal cosmetics, which is indicated by an average score of $88.53 \%$. Trust in halal cosmetics is indicated by the responses of the respondents of this study, there are (1) believing that they must strictly prohibit themselves from using non-halal cosmetics as taught in Islam; (2) they believe that using non-halal cosmetics is a sin for Muslims; (3) and they believe that using halal cosmetics is obedient to Islamic orders. This response is a belief in the guidelines, rules, and scores contained in religious beliefs. Islam is a system of beliefs and comprehensive actions that govern faith, individuals and society and transcend the material world. According to Umar Chapra (2008) the main basis of Islamic rules is Sharia. Sharia refers to scores and institutions or regulations to make people fulfill their obligations and prevent social damage to ensure the enforcement of justice, development and achievement of well-being for all. Sharia Islam regulates all aspects of life including consumption behavior. Including regulating cosmetics that may be used by Muslims, namely halal cosmetics.

In addition to believing, adult women who are Muslim and domiciled in Medan city also strongly agree that halal cosmetics are cosmetics that are good for health, which are free from harmful ingredients and produced hygienically with an average score of $89.65 \%$. This is in line with the opinion of Qardhawi (1995), which is one that must be fulfilled in consumption, namely: consumption of good goods (thayyib). Abû Bakr Ibn al-rArabîn clarifies the meaning of "thayyib" which is something that is appropriate for the body and feels delicious and something that is permitted by Allah.

The research findings also show that religious beliefs and health are factors that affect the consciousness of Muslim adult women in Medan to use halal cosmetics. Based on these findings, religious beliefs have a positive and significant effect on the level of consumer consciousness using halal cosmetics where $0.368>0.05$ and produces a t score of statistics $4.794>t$ table 1.96, which shows a positive and significant effect. These findings are in line with the opinion of Schiffman \& Kanuk, namely that members of various purchasing decisions of religious groups are effected by their religious beliefs, identity, orientation, knowledge and trust. The findings of this study are in line with previous research, namely Abdul Raufu's research (2014) which shows that increasing demand for halal consumption is aided by a number of potential factors or sources identified, one of which is religious belief. Likewise in the study of Azmawani (2013), there is a positive relationship between religious beliefs and consumer attitudes towards halal cosmetics.

Health factors have a positive and significant effect on the level of consumer consciousness using halal cosmetics, that is $0.477>0.05$ and produce a t statistic score of 5.098 $>\mathrm{t}$ table 1.96, which shows a positive and significant effect. This finding is in line with the opinion of Mu'rifah (2007) about personal health, namely that someone will try to maintain and 
increase their own level of health in order to achieve peace of life and have the best workforce. Likewise in the study of Azreen Jihan (2014) in line with these findings, that is the content or ingredients of cosmetic products is a factor that can affect them to consume cosmetic products. Health factors also in this research are variables that have more effect on the level of consciousness of consumers using halal cosmetics compared to religious beliefs. This is in line with the research of Ambalia and Bakara (2014) that health factors are the variables that most effect the level of halal consciousness. The implication here is that the authorities or policy makers must know that halal cosmetics are not only a matter of religious beliefs but a global symbol to guarantee the quality of the world consumer lifestyle. Because halal provides health effects, well, clean, beautiful and sacred. All of these elements are in the concept of Islam. Then the important government considers the halal concept to make regulations or take policies in producing cosmetics and supervising cosmetics circulating in the market. So that consumers are protected from harmful cosmetics.

\section{Conclusion}

Based on the finding and discussion of the study it can be concluded that adult women who are Muslim and domiciled in Medan city are very aware of using halal cosmetics. This is indicated by health factors and religious beliefs positive and significant effect on consumer consciousness of using halal cosmetics. They are aware because besides being sacred, halal cosmetics have positive effects such as health, good, clean, and free from harmful ingredients.

\section{References}

Abd Rahman, Azmawani dan Ebrahim Asrarhaghighi Suhaimi Ab Rahman. (2014). Consumers and Halal cosmetic products: knowledge, religiosity, attitude and intention. Journal of Islamic Marketing, Vol. 6 Iss 1 pp. Emerald Group Publishing Limited

Abû Bakr Muhammad ibn 'Abd Allâh Ibn al-'Arabî. (1405H). Ahkam Al- Qur'an, (Bayrût: Dâr al-Fikr, t.th), jilid II, p. 32. Rewritten by Ibn al-'Arabî.

Ambalia, Abdul Raufu and Bakara, Ahmad Naqiyuddin. (2014) People's Consciousness on Halal Foods and Products: Potential Issues for Policy-Makers, The Journal of international Procedia - Social and Behavioral Sciences $1213-25$.

Aoun, Isabelle and Laurent Tournois. (2015). Building brand holistic: an exploratory study of Halal cosmetics. Journal of Islamic Marketing. 2015.Vol. 6 Iss 1. Emerald Group Publishing Limited

Chartrand, T. L. (2005). The role of conscious consciousness in consumer behavior. Journal $\begin{array}{llll}\text { of } \quad \text { Consumer } & \text { Psychology, } & 15(3), & 203\end{array}$ http://dx.doi.org/10.1207/s15327663jep1503_4

Chin, W.W. (1998). “The partial least squares approach to structural equation modeling”. In G.A.Marcoulides (Ed.), Modern Methods for Business Research, N.J., Lawrence Erlbaum Associates: Mahwah.

Fornell, C. and Larcker, D. F. 1981. Evaluating Structural Equation Models with Unobservable Variables and Measurement Error. Journal of Marketing Research, 18(1): 39-50. 
Jihan, Hashim, and Rosidah Musa. (2014). Factors Influencing Attitude Towards Halal Cosmetic Among Young Adult Urban Muslim Women: A Focus Group Analysis. Procedia - Social and Behavioral Sciences 130129 - 134. (www.sciencedirect.com)

Mudrajad Kuncoro, 2003, Metode Riset Untuk Bisnis dan Ekonomi, Jakarta, Publisher : Erlangga, p. 113.

Mu'rifah. (2007). Materi Pokok Pendidikan Kesehatan. Jakarta: Universitas Terbuka

M. Umar Chapra. (2008). Ibn Khaldun Teori Does it help ecplain the Low Performance of The Present-Day Moeslem World?. Jurnal Sosial Ekonomi. 37 836-863

Laporan GIEI-Thompson Reuters 2014 s.d 2017, processed

Schiffman L.G. \& Kanuk, L.L. (1997). Consumer behaviour N.J. Prentice-Hall. Natsoulas, T. (1999). The Concepts of Consciousness 6: The General State Meaning. Journal for the Theory for Social Behavior, 20, 1

Yusuf al-Qardhawi. 1995. Peran Nilai dan Moral dalam Perekonomian Islam. Jakarta: Rabbani Press, p.37

Tenenhaus, M. et al. 2005. PLS Path Modeling. Computational Statistics and Data Analysis, 48 (1): $159-364$ 